Article

\title{
Effects of Collaborative Economy: A Reflection
}

\author{
Antonio Menor-Campos *, María de los Baños García-Moreno $\mathbb{D}^{\text {, }}$, Tomás López-Guzmán $\mathbb{D}$ and \\ Amalia Hidalgo-Fernández \\ Agrifood Campus of International Excellence ceiA3, University of Cordoba, 14005 Cordoba, Spain; \\ d52gagam@uco.es (M.d.1.B.G.-M.); tomas.lopez@uco.es (T.L.-G.); ahidalgo@uco.es (A.H.-F.) \\ * Correspondence: antonio.menor@uco.es; Tel.: +34-957-212-507
}

Received: 24 February 2019; Accepted: 3 May 2019; Published: 7 May 2019

check for updates

\begin{abstract}
Collaborative economy, a practice based on access to goods, is making its way into society, with disruptive effects for traditional economy, which is based on property. Although it is a recent phenomenon, its rapid growth and user acceptance make it possible to predict that in the near future, collaborative economy will be an important pillar of economic growth and employment. The results of this research indicate the existence of other effects of the collaborative economy, not always desirable, among which are changes in mentality or the appearance of new business models.
\end{abstract}

Keywords: collaborative economy; p2p accommodation; car sharing; crowdfunding

\section{Introduction}

In recent years, the old practice of sharing has grown significantly and has given rise to a new phenomenon known as 'collaborative economy'. Owing to the innovative nature of this movement and its recent origins, there is still some discrepancy about its definition and other issues (Murillo et al. 2017; Tescasiu et al. 2018). Different terms have been used to refer to collaborative economy, and many of these have different meanings but overlap in some aspects. 'Sharing economy' (Byers et al. 2013; Cohen and Kietzmann 2014; Nadler 2014; Schor 2014; Hamari et al. 2015; Sung et al. 2018), 'collaborative consumption/economy' (Belk 2014; Hamari et al. 2015; Möhlmann 2015; Ertz et al. 2018), 'access-based consumption/economy' (Bardhi and Eckhardt 2012), 'peer to peer economy' (Bellotti et al. 2015; Weber 2016), 'gig economy' (De Stefano 2016; Todolí-Signes 2017; Zwick 2017; Petriglieri et al. 2019) or 'economy of access' (Denning 2014; Gadellaa 2017) are some of the terms used (Acquier et al. 2019). Following Ertz et al. (2018, p. 7) collaborative economy can be defined as the set of resource circulation schemes that enable consumers to both receive and provide, temporarily or permanently, valuable resources or services through direct interaction with other consumers or through an intermediary'. Acquier et al. (2019) define sharing economy as a group of initiatives that improve the availability and efficiency of sub-utilised resources through exchanges between participants or promoting access over ownership. Our concept of collaborative economy is related to these two definitions and includes models that allow participants to play the role of providers and receivers of infra-utilised goods or services, making the transaction easier and reducing its costs, where the interaction can occur either directly or through an intermediary such as a digital platform, and includes both free services and those that require some type of compensation.

The effects of collaborative economy are varied and include aspects such as changes in citizens' mentality and way of thinking, and in professional relationships or even basic economic sectors such as accommodation and transport. Some of these effects are positive and contribute to meeting the needs of users, while other effects could lead to deterioration in job quality or increases in social inequality. This paper reviews the published research on the effects that collaborative economy has or could have on society. The methodology used to reach this objective is based on the consultation of Scopus and the Web of Science (WoS) databases using key words. 


\section{Literature Review}

In its report to the European Commission (Daveiro and Vaughan 2016), PriceWaterhouseCoopers (PwC) distinguishes five key sectors within collaborative economy: peer-to-peer accommodation, peer-to-peer transportation, on-demand household services, on-demand professional services, and collaborative finance. There are also studies from the European Commission about the impact of collaborative economy on the accommodation sector within the tourism industry (European Commission 2018), on the labour market (De Groen and Maselli 2016; Pesole et al. 2018), and on consumers (Jourová 2017).

\subsection{Main Sectors Affected}

The peer-to-peer accommodation sector includes both shared access to spaces available at home and, for example, the lease of a house to travellers during holidays. It includes modalities as diverse as 'house swapping', 'couchsurfing', 'warmshowers' for bikers, or 'nightswapping'. In some of these modalities (couchsurfing, warmshowers) there is no compensation for the services rendered (Jarne-Muñoz 2016), while in others (house swapping, nightswapping) there is reciprocity between the participants (Andriotis and Agiomirgianakis 2013). There are also modalities in which a monetary compensation is paid (as in the case of Airbnb). It is important to note that this sector already accounted for more than $50 \%$ of operations carried out in Europe within the scope of collaborative economy in 2015 (Daveiro and Vaughan 2016).

The collaborative transport sector includes operations that involve sharing a means of transport, a car, or a parking space (Daveiro and Vaughan 2016). Some of the modalities of this sector of collaborative economy imply more efficient vehicle use and, with it, a positive impact on the environment and road traffic in cities (Teubner and Flath 2015). Others, on the other hand, allow individual access to a vehicle (in which the positive contribution to the environment and the decrease in traffic in the cities do not seem to be significant) to satisfy the user's need to move more comfortably (Bardhi and Eckhardt 2012). There have also been studies on the reduction of fatal accidents due to alcohol consumption after the introduction of certain collaborative transport services (Greenwood and Wattal 2017). As in the previous case, the importance of this sector in the total collaborative economy in Europe, where it represents $18 \%$ of operations in the continent and $47 \%$ of the profits generated, must be highlighted (Daveiro and Vaughan 2016).

The sector of on-demand household services occupies the third place in benefits generated (within the European scope) at 12\% (Daveiro and Vaughan 2016). The operations contemplated include services provided at home, generally in the peer-to-peer area, coordinated by a technological platform. Due to the increase in the number of people who offer their services and obtain an income from this type of platform-between 300\% and 440\% (JPMorgan 2015), and the high number of users offering their services, it is easy to conclude that, for consumers, being able to easily find what is needed is an attractive alternative (Melián-González 2017). Some authors warn of the precariousness and low rewards that the service providers obtain: the platforms decide, through complex algorithms, who is shown, when they are displayed, and what is shown, and have the ability to change the algorithm or the criteria used at any time and without taking the bidders into account (Ravenelle 2017). These same criticisms may be applied to the professional on-demand services sector. The distinction between the two would be in the professional or domestic nature of the services (e.g., Uber and TaskRabbit, respectively) (Melián-González 2017). In the case of professional services, the platform creates a channel for service providers, allowing them to expand, while in the case of domestic services, platforms create new markets for new and different forms of autonomous work (Sundararajan 2014). Alfonso-Sánchez (2016) speaks of 'platform cooperativism', a movement that advocates for platforms to be owned by users-both the providers of services or goods and the consumers—thus preventing third parties from profiting from the work or goods of users.

The last sector, collaborative finance, includes services related to financing, either in the form of investment ('crowdfunding') or in the form of a loan ('peer-to-peer lending'), collective currencies, 
and collaborative insurance policies (Alfonso-Sánchez 2016). Crowdfunding can be defined as the set of efforts on the part of entrepreneurs - both individual and collective- to finance their projects through small contributions from a large number of individuals using the Internet, without the participation of traditional financial intermediaries (Mollick 2014). Instead of going to a small group of specialised investors, many individuals are approached, each of whom contributes a small amount (Belleflamme et al. 2014). Following Mollick (2014), the term crowdfunding encompasses several variants:

- Patronage model: the sponsors play an altruistic role, without expecting any concrete compensation for their contribution.

- Loan model: the funds are offered as loans, with the hope of obtaining a profit and return on capital.

- Reward model: rewards are very common and may consist of being mentioned in a film, participating in the creation of a product, knowing the authors of a specific project, or having access to the product in advantageous conditions.

- Business participation model ('equity crowdfunding'): investors acquire the status of partners in the project.

Other authors (Belleflamme et al. 2014) have considered two models of crowdfunding: 'pre-ordering' and 'profit sharing'. In the first model, entrepreneurs encourage consumers to pre-order the product to obtain the necessary financing to start the project. In the second, the entrepreneurs ask for money from people in exchange for sharing the future benefits of the project.

Peer-to-peer lending uses digital platforms to connect an individual who needs funds with other individuals who are interested in lending (Bruton et al. 2015; Emekter et al. 2015). The user receiving the loan obtains more competitive interest rates, while the user who lends the money obtains a return that is generally higher than that from a credit institution (Emekter et al. 2015). To facilitate transactions, platforms usually establish various measures to ensure the trust between the lender and the borrower, which may include relationships through social networks with other users of the same or similar platforms (Freedman and Jin 2017; Ge et al. 2017).

\subsection{Implications of Collaborative Economy}

Following Ertz and Sarigöllü (2019) and Frenken and Schor (2017), the emergence of the collaborative economy has involved a series of economic, social, and environmental changes.

\subsubsection{Economics Effects}

We have detected three main effects related to economic changes brought about by collaborative economy: the transition to an economy based on use, the emergence of new economic actors, and the dramatic appearance of a new business model. Following Arnould and Rose's (2016), and Ertz et al. (2018), it is necessary to take into account the existence of some form of compensation. Thus, we must use the 'sharing' concept when there is no compensation, and 'pooling/mutualizing for a compensation' if there is any form of compensation such as object, service, points, money, or something similar.

Transition to an economy based on use. Society is moving from an economy based on property to an economy based on use, that is, from 'you are what you have' to 'you are what you can use' (Belk 2014). Owning something that we only use a few minutes a year does not make sense if we can access that good specifically when we need it (Botsman and Roo 2010). This does not change the object of consumption, but rather the manner of consuming the product. The reasons for this change are diverse: some are of an altruistic nature, such as the feeling of collaborating with the sustainability of the environment, while others are more prosaic, such as obtaining an economic benefit, either by gaining an income or by saving on the acquisition or use of the product (Hamari et al. 2015).

The segment of the population that is traditionally associated with collaborative economy and that tends to show a greater propensity to share is the generation known as 'Millennials' 
(Hwang and Griffiths 2017; Ranzini et al. 2017). The Millennial generation include those born from the beginning of the 1980s until the beginning of the twenty-first century. This cohort seems to be influenced by their social environment—both physical and virtual—and by the search for variety and exclusivity in shared goods (Amaro et al. 2018). Millennials seem to be less attracted to owning a house and more willing to use public or shared transportation rather than purchase a vehicle of their own (McDonald 2015; Ranzini et al. 2017). This seems to go against what has been found in other studies (Xu et al. 2015), which have argued that more than 85\% of Millennials have the objective of purchasing a house, considering this option preferable to renting. In fact, Garikapati et al. (2016) point out that as Millennials grow, they tend to adopt behaviours and attitudes like those of previous generations; thus, the great change in the economy in which they were supposed to participate could not happen.

Sharing is an activity that feeds back: people are driven to share when someone has shared with them-although they will not necessarily share with the same person (Hyde 1983). Certain assets are more 'shareable' ('shareable goods') than others, and the definition of shareable can vary depending on the subject's level of income (Benkler 2004). There are two possible modalities when sharing a good. The first ('sharing in') occurs within groups of individuals or communities united by family, friendship, or neighbourhood ties. The second modality ('sharing out') occurs between strangers and, being commercialised, entails a compensation ('pooling/mutualizing for a compensation'), generally economic (Belk 2017). In either case, the activity of sharing something has been reinforced by Web 2.0, particularly in social networks, where users share content with each other and both shared production and shared consumption are found (John 2013).

New actors in collaborative economy. Collaborative economy is based on the creation of common spaces where users make exchanges either directly or through platforms that allow them to acquire, sell, rent, lend, or give/donate using technologies that facilitate the generation of trust, confidence, and information reciprocity with very low transaction costs and coordination (Cañigueral 2016; Lan et al. 2017). Not only start-ups are involved in these operations, but other actors participate as well, as indicated in Table 1. Although some of these are not, strictly speaking, new actors, we have included them for their connection with the idea of prevalence of access over ownership (as in the case of municipal libraries, which can be a meeting space where people can access books without having to buy it). In Table 1, we differentiate between actors who seek profit (the person who rents his car or his house), actors with other motivations like reputation or recognition or even social or environmental concerns. We can also see actors whose main purpose is related to the community, where technology's role is less relevant than for other actors, but there is a strong emphasis on contact and human relationships. The last role, the public sector, comprises heterogeneous services including bicycle shares or local currencies.

Table 1. Actors in collaborative economy.

\begin{tabular}{|c|c|c|}
\hline Purpose/Role & Definition & Examples \\
\hline For profit & $\begin{array}{l}\text { For-profit entities that carry out purchase/sale, } \\
\text { rental, loan, exchange, or gift/donation activities } \\
\text { with the help of information technologies that } \\
\text { significantly reduce transaction costs and } \\
\text { facilitate exchanges between strangers. }\end{array}$ & \begin{tabular}{ll}
\multicolumn{2}{l}{ International: } \\
- & Airbnb \\
- & BlaBlaCar \\
- & EBay \\
- & Car2Go \\
Local: \\
- & Wallapop \\
- & SocialCar \\
- & Percentil \\
- & Trip4real
\end{tabular} \\
\hline Non-profit & $\begin{array}{l}\text { Like profit companies, but actors are non-profit, } \\
\text { that is, their main motivation is to advance their } \\
\text { mission and/or purpose. }\end{array}$ & $\begin{array}{ll}\text { - } & \text { Goteo } \\
\text { - } & \text { Shared orchards } \\
\text { - } & \text { Freecycle } \\
\text { - } & \text { Reutiliza.cat } \\
\text { - } & \text { NoLoTiro.org }\end{array}$ \\
\hline
\end{tabular}


Table 1. Cont.

\begin{tabular}{|c|c|c|}
\hline Purpose/Role & Definition & Examples \\
\hline Social Enterprise/Co-operative/B Corp & $\begin{array}{l}\text { Like non-profit entities, with the exception that } \\
\text { social and environmental motivations have } \\
\text { priority over economic profit. In cooperatives, } \\
\text { ownership is shared. }\end{array}$ & $\begin{array}{ll}\text { - } & \text { SomMobilitat } \\
\text { - } & \text { Banks of time } \\
\text { - } & \text { CiviClub } \\
\text { - } & \text { Ecrowd } \\
\text { - } & \text { RobaAmiga }\end{array}$ \\
\hline Community & $\begin{array}{l}\text { Actors focused on the local and/or } \\
\text { neighbourhood levels, with a variety of legal } \\
\text { structures, although non-profit entities and } \\
\text { informal models are the most common. Most } \\
\text { transactions are not monetised. } \\
\text { The use of information technologies is more } \\
\text { modest, with an emphasis on contact and human } \\
\text { relationships. } \\
\text { Often explicitly, one of its purposes is to achieve } \\
\text { sustainability at the local level. }\end{array}$ & $\begin{array}{l}\text { - } \quad \text { SocialToy } \\
\text { - } 1010 \text { ways to buy without money } \\
\text { - } \quad \text { Community gardens } \\
\text { - } \quad \text { Bansumer groups } \\
\text { - } \quad \text { EcoXarxes } \\
\text { - } \quad \text { PetitBus }\end{array}$ \\
\hline Public sector & $\begin{array}{l}\text { Unlike the cases above, public sector entities are } \\
\text { subject to rigorous standards of responsibility, } \\
\text { transparency, and legitimacy. They can use their } \\
\text { most sophisticated infrastructure to support or } \\
\text { arrange agreements with other players to } \\
\text { promote new ways of sharing, although they } \\
\text { have to meet the interests of citizens and } \\
\text { governing bodies. }\end{array}$ & $\begin{array}{l}\text { - } \quad \text { Municipal libraries } \\
\text { - } \quad \text { Phared bicycle services } \\
\text { fublic purchase with criteria in } \\
\text { - } \quad \text { Local of currencies with } \\
\text { municipal support }\end{array}$ \\
\hline
\end{tabular}

Source: Own elaboration adapted from Cañigueral (2016).

New business models. Collaborative economy has brought together a great diversity of business models that oscillate between capitalist platforms (Srnicek 2017) and those with a cooperative approach. The appearance of these new business models based on the exchange of goods and/or services through technological platforms is another important effect of collaborative economy. These new models, characterised by very low transaction and coordination costs, allow users to operate and carry out transactions that would not be possible in the traditional economy. The following figure (Cohen and Muñoz 2016, Figure 1) shows the key aspects of the new companies in collaborative economy, following the 'Sharing Business Model Compass' (SBMC).

This model is used at the EADA Business School and the University of Leeds, where its authors (Cohen and Muñoz 2016) are based, and can be used by public authorities to develop specific standards for each business model (Cañigueral 2016). The model, as shown in Figure 1, consists of six dimensions: technology, transaction, business focus, shared resources, governance model, and platform type. Each dimension has three degrees. Of these dimensions, four range from market-based models to cooperatives (transaction, business model, governance, and type of platform). Models based on the other two dimensions can use any of the three options reflected (Cañigueral 2016). It is important to highlight that Cañigueral (2016) used an extended concept of participants/consumers which includes not only individuals/natural persons but also companies/legal entities. Therefore, it is possible to find a business-to-business platform in the model, even if its location in the model is almost out of the sharing core, on the third level, near to a market model. Moving in a clockwise direction, the location of a specific case within collaborative economy can be analysed. As long as it is located on the most external levels, it is a business model, while the interior zone focuses on platforms whose objective is shared use, without a profit motive. A comparison of Airbnb and Couchsurfing, for example, yields the results shown in Table 2. 


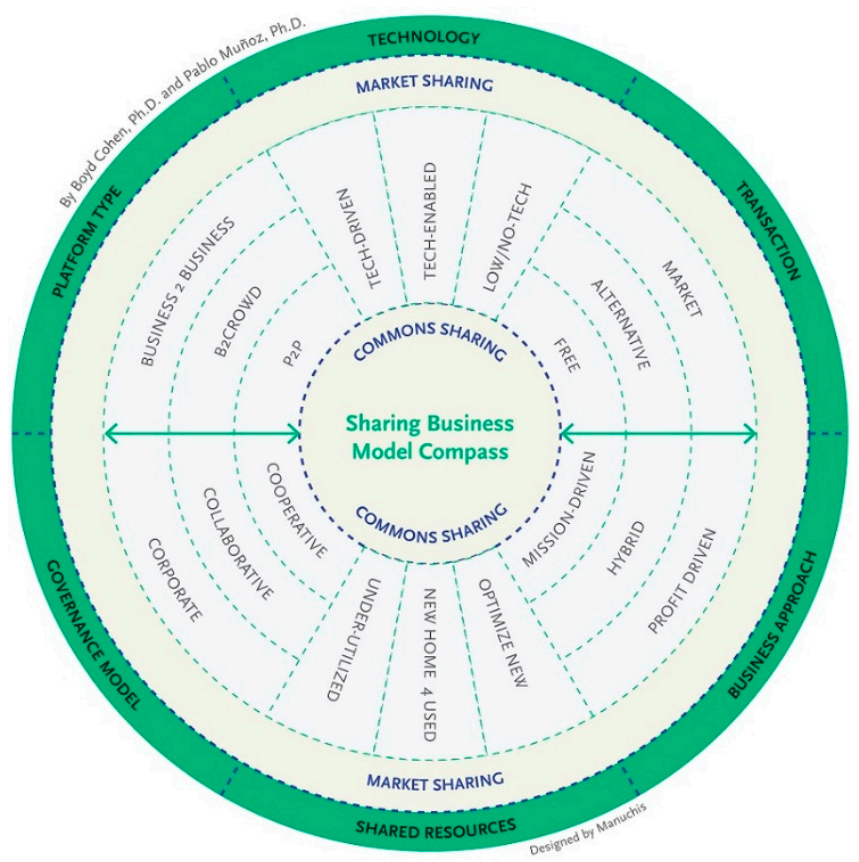

Figure 1. Sharing Business Model Compass (SBMC). Source: Cohen and Muñoz (2016).

Table 2. Dimensions assigned to Airbnb and Couchsurfing.

\begin{tabular}{lll}
\hline Dimension & Airbnb & Couchsurfing \\
\hline Transaction & Market & Free \\
Business approach & Profit-driven & Mission-driven \\
Governance Model & Corporate & Collaborative \\
Platform Type & Business to crowd & Peer-to-peer (P2P) \\
\hline
\end{tabular}

The technology and shared resources dimensions are only descriptive, and their parallel choices have no effect on business model orientation. When we draw the lines for each model, we can see clear differences between them. One is very close to the market model (Figure 2), while the other one (Figure 3) is very close to the commons sharing model. 


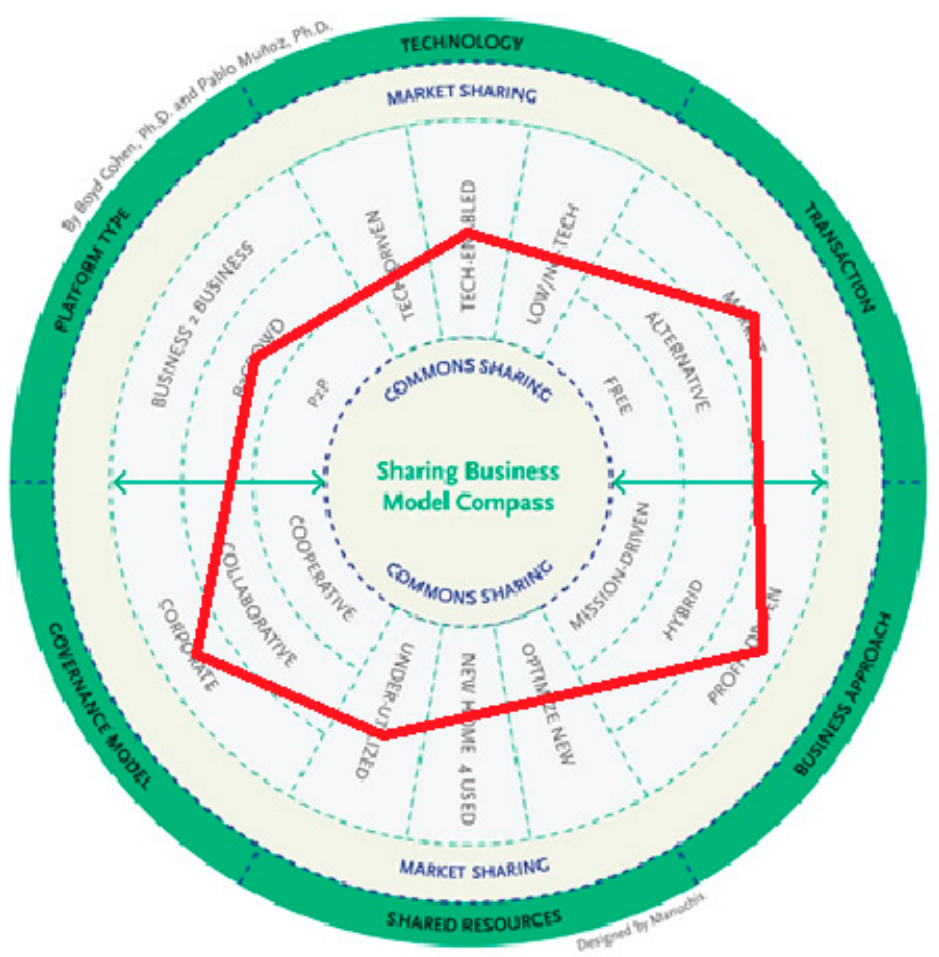

Figure 2. SBMC applied to Airbnb. Source: Cohen and Muñoz (2016).

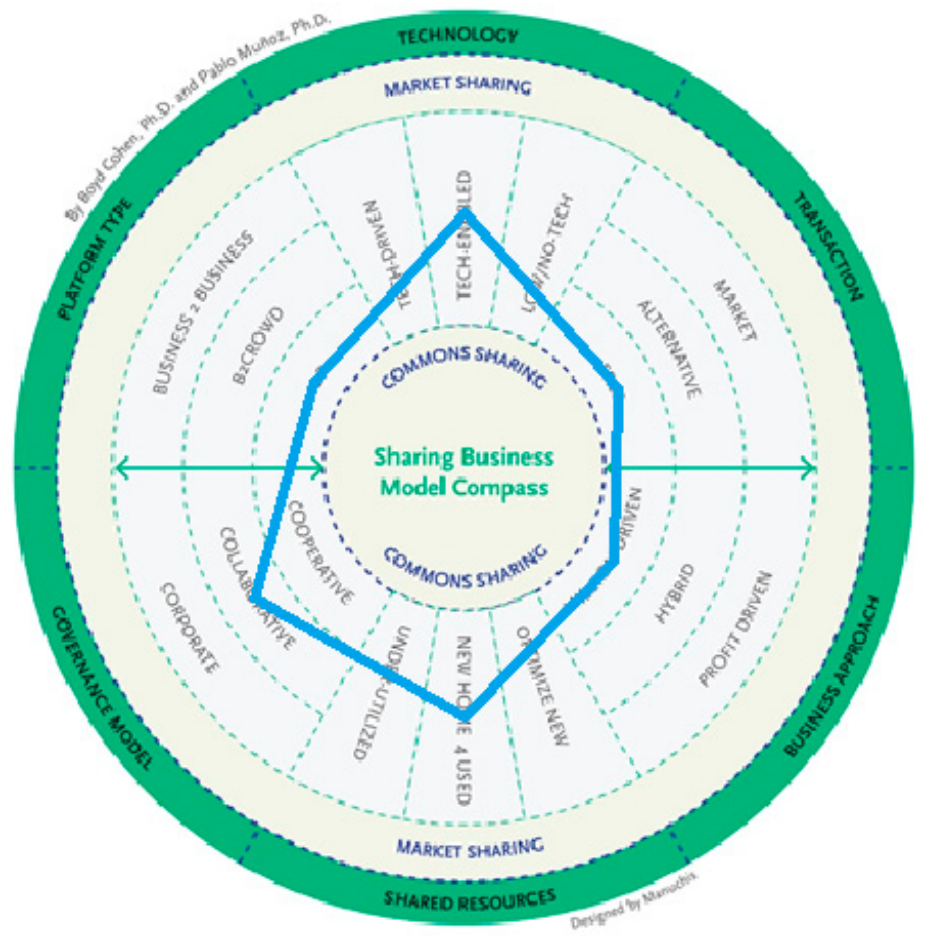

Figure 3. SBMC applied to Couchsurfing. Source: Cohen and Muñoz (2016).

Another classification of collaborative resource circulation systems can be found in Ertz et al. (2016), who describe each resource circulation system in terms of three dimensions: collaborative intensity (sourcing, trading, pure), collaborative consumption (yes/no), and consumer process (delegation, quasi-empowerment, empowerment). 


\subsubsection{Social Effects}

In this section, we include the effects that have a relevant social impact, including changes in people's mindset, impact on professional conditions, and the rise of inequality or discrimination between users.

Changes in people's mindset. There has been a change in user mindset concerning trust in strangers and security. Transactions are now made between strangers that would have been unthinkable a few years ago (Ert et al. 2016; Botsman 2017; Ter Huurne et al. 2017). Users take risks—such as sharing a house or car with, borrow money from, or buying food for strangers-to obtain an economic benefit or enjoy an attractive service, and these risks, despite the efforts of the platforms, are not always covered (Schwartz and Oster 2018). Feeney (2015) points out a growing concern, which is encouraged by sectors of the traditional industry such as the taxi sector or the hotel industry, for the safety of the users of these services, highlighting certain problems that exist in this type of service: first, the risk involved in car or house sharing with a stranger; second, and with reference to the transport sector, the fact that because the drivers of these companies are individuals who dedicate themselves to these activities in a partial and non-professional manner, there can be conflicts regarding insurance coverage, as insurers usually differentiate between private and professional drivers. Finally, Feeney (2015) also points out the regulatory gap in making the platform responsible for the behaviour of its users (suppliers or consumers of services). However, for other authors (Dills and Mulholland 2015), the introduction of the services of these companies in the transport sector has meant a decrease in fatal traffic accidents that is estimated to range from $17 \%$ to $40 \%$ once the companies have operated for more than 4 years in the area. According to these same authors (Dills and Mulholland 2015), no evidence has been found that the inhabitants of areas where these companies operate are more likely to suffer robbery or assault since they began to provide their services; on the contrary, a decrease in arrests for 'disorderly conduct' is suggested. In fact, other studies (Park et al. 2016) point to a decrease in sexual crimes since the introduction of services from companies such as Uber and Lyft.

Companies have reacted to safety concerns in different ways, depending on the sector in which they operate. In the accommodation sector, it is common to acquire millionaire insurance policies that cover the owners for possible damage by users (Etzioni 2017), while in the transport sector, the requirements for being an Uber or Lyft drive have increased and are now well above those required by traditional taxi companies.

Effects on professional conditions. The impact of constant technological change on the traditional economic model, and the new perceptions and social attitudes that the new economy has brought are difficult to quantify. An emerging society with new motivations drives new forms of work (Sagardoy-de-Simón and Núñez-Cortés-Contreras 2017, p. 94). Thanks to new technologies, new types of jobs are being created. Many of these new occupations are based on self-employment, require a high level of creative skills, have a marked entrepreneurial character and benefit from low initiation and marketing costs (Berger and Frey 2006). These new types of services bring benefits both for the worker (access to job opportunities, obtaining professional experience, recognition, flexibility, increased productivity, or income) and for the person who requires their services (access to specific skills that are not easy to locate by other means, participation in creation, cost savings, variety of available solutions, scalability, or increase in productivity; see, e.g., Mtsweni and Burge 2014; Ertz and Sarigöllü 2019). There is, however, no security in the demand, which results in precariousness and lack of income stability (Melián Gonzalez and Gideumal 2015), and social protection does not exist or is lower than that obtained by a traditional employee (Auvergnon 2016). Sharing companies have also strongly resisted regulatory attempts from local authorities (Smorto 2016).

However, the existence of the so-called 'uber economy', born with the camouflage of collaborative economy, has led to the growth of 'work on demand' ('jobbing'). These jobs have a high degree of precariousness (if there is no demand, there is no work), with revenues mediated by companies (with maximum pricing policies), and conditions set by companies too (Sagardoy-de-Simón and Núñez-Cortés-Contreras 2017); additionally, these jobs are unstructured and unprotected 
(Auvergnon 2016; Freedland and Prassl 2017), precarious (Malin and Chandler 2017) and, in general, with worse working conditions than conventional employment (Cockayne 2016; Schor 2017; Schor and Attwood-Charles 2017). It is therefore necessary to question the adequacy of the current labour legislation, created for a traditional economy, for the new situations that collaborative economy creates. Considering how to adapt these regulations is paramount (Ginés-i-Fabrellas and Gálvez-Durán 2016).

Possibility of discrimination. Fremstad (2017) has suggested differences in the propensity to share goods depending on socio-economic level, with people with a medium-high income being more likely to share using the new technology platforms. This leads to one of the most criticised aspects of collaborative economy, which is the possibility that people from a low socio-economic level cannot enjoy its benefits because they have no means to access it (e.g., computers or mobile devices, Internet connection, etc.). In fact, the peer-to-peer nature of collaborative economy can increase discrimination among users themselves (Frenken and Schor 2017). This point of view contrasts, however, with the results obtained by other authors (Dillahunt and Malone 2015) studying the perception of collaborative economy in groups with the worst economic situation, where the predominant opinion is that collaborative economy will help people find a job or save money. Accordingly, if participation in collaborative economy is examined adjusting the data according to the ease/difficulty of certain social groups to access the Internet, the result shows that collaborative platforms receive more use from individuals with low income (Fremstad 2017).

\subsubsection{Environmental Effects}

The shift from an economy based on ownership to an economy based on access leads to more efficient use of underutilised goods and, at the same time, reduces the level of industrial production, creating a positive impact on the environment (Botsman and Roo 2010; Belk 2014; Acquier et al. 2019). However, the environmental effects of collaborative economy are complex and although it is true that sharing implies lower resource consumption by reducing the demand for new goods, it is not clear whether this reduction is balanced with the growing use of resources created by increased access for people not using these goods before (Frenken and Schor 2017; Ertz and Sarigöllü 2019). This is particularly relevant in the case of car sharing, where the low price may cause a decrease in the use of public transport and increase $\mathrm{CO}_{2}$ emissions, congestion, and pollution, generating a rebound effect (Ertz and Sarigöllü 2019). The consideration of such secondary effects is necessary to avoid what Frenken and Schor (2017) call 'partial-equilibrium analysis', in which only first round effects are considered, but not the secondary ones. It is also quite possible that the income obtained through collaborative activities are used to buy new goods, thus increasing the environmental impact.

\section{Conclusions}

Collaborative economy has expanded in five main sectors: accommodation, transportation, on-demand household services, on-demand professional services, and finance. The effects generated differ according to the sectors and are debated in the academic literature, with no clear consensus on their nature. While some studies defend the positive environmental contribution, as sharing reduces the amount of goods that must be produced, others question this effect in sectors such as transport, as the services of collaborative economy discourage the use of public transport in favour of private transport, which would increase pollution and congestion in the cities. From a labour perspective, there seems to be consensus in the academic literature on the enormous potential of collaborative economy to create jobs, although for many authors the problem lies in the precarious nature of these positions, which are often linked to the existence of demand for certain services and have lower salaries than those in the traditional economy. Meanwhile, in the financial sector, the emergence of platforms for financing projects by individuals has facilitated access to credit in an economic situation in which financing was particularly difficult to obtain.

The practical application of this research focuses on establishing a theoretical framework that opens new lines of research. Future empirical studies should be conducted to validate the theoretical basis. 
Author Contributions: Investigation, A.M.-C., M.d.I.B.G.-M., T.L.-G. and A.H.-F.; Writing—original draft, A.M.-C., M.d.l.B.G.-M., T.L.-G. and A.H.-F.; Writing-review \& editing, A.M.-C.

Funding: This research received no external funding.

Conflicts of Interest: The authors declare no conflict of interest. The funders had no role in the design of the study; in the collection, analyses, or interpretation of data; in the writing of the manuscript, or in the decision to publish the results.

\section{References}

Acquier, Aurélien, Valentina Carbone, and David Massé. 2019. How to Create Value(s) in the Sharing Economy: Business Models, Scalability, and Sustainability. Technology Innovation Management Review 9: 5-24. [CrossRef]

Alfonso-Sánchez, Rosalía. 2016. Economía Colaborativa: Un nuevo mercado para la economía social. Paper presented at XVI Congreso de Investigadores en Economía Social y Cooperativa, Murcia, Spain, October $19-21$.

Amaro, Suzanne, Luisa Andreu, and Shenhua Huang. 2018. Millenials' intentions to book on Airbnb. Current Issues in Tourism. [CrossRef]

Andriotis, Konstantinos, and George Agiomirgianakis. 2013. Market Escape Through Exchange: Home Swap as a Form of Non-Commercial Hospitality. Current Issues in Tourism 17: 576-91. [CrossRef]

Arnould, Eric J., and Alexander S. Rose. 2016. Mutuality: Critique and substitute for Belk's "sharing". Marketing Theory 16: 75-99. [CrossRef]

Auvergnon, Philippe. 2016. Angustias de uberización y retos que plantea el trabajo digital al derecho laboral. Revista Derecho Social y Empresa 6: 1-18.

Bardhi, Fleura, and Giana M. Eckhardt. 2012. Access-based Consumption: The Case of Car Sharing. Journal of Consumer Research 39: 881-98. [CrossRef]

Belk, Russell. 2014. You Are What You Can Access: Sharing and Collaborative Consumption Online. Journal of Business Research 67: 1595-600. [CrossRef]

Belk, Russell. 2017. Sharing without Caring. Cambridge Journal of Regions, Economy and Society 10: $249-61$. [CrossRef]

Belleflamme, Paul, Thomas Lambert, and Armin Schwienbacher. 2014. Crowdfunding: Tapping the Right Crowd. Journal of Business Venturing 29: 585-609. [CrossRef]

Bellotti, Victoria, Alexander Ambard, Daniel Turner, Christina Gossmann, Kamila Demkova, and John M. Carroll. 2015. A Muddle of Models of Motivation for Using Peer-to-Peer Economy Systems. Paper presented at 33rd Annual ACM Conference on Human Factors in Computing Systems-CHI '15, Seoul, Korea, April 18-23. [CrossRef]

Benkler, Yochai. 2004. Sharing Nicely: On Shareable Goods and the Emergence of Sharing as a Modality of Economic Production. The Yale Journal 114: 273-358. [CrossRef]

Berger, Thor, and Carl Benedict Frey. 2006. Bridging the Skills Bap. London: Institute for Public Policy Research, pp. $40-42$.

Botsman, Rachel. 2017. Who Can You Trust? London: Random Penguin House UK.

Botsman, Rachel, and Rogers Roo. 2010. What's Mine Is Yours. New York: HarperCollins.

Bruton, Garry, Susanna Khavul, Donald Siegel, and Mike Wright. 2015. New Financial Alternatives in Seeding Entrepreneurship: Microfinance, Crowdfunding, and Peer-To-Peer Innovations. Entrepreneurship: Theory and Practice 39: 9-26. [CrossRef]

Byers, John, Davide Proserpio, and Georgios Zervas. 2013. The Rise of the Sharing Economy: Estimating the Impact of Airbnb on the Hotel Industry. SSRN Electronic Journal 13: 1-36. [CrossRef]

Cañigueral, Albert. 2016. Hacia una economía colaborativa responsable. Oikonomics 6: 16-27.

Cockayne, Daniel G. 2016. Sharing and Neoliberal Discourse: The Economic Function of Sharing in the Digital On-Demand Economy. Geoforum 77: 73-82. [CrossRef]

Cohen, Boyd, and Jan Kietzmann. 2014. Ride On! Mobility Business Models for the Sharing Economy. Organization E Environment 27: 279-96. [CrossRef]

Cohen, Boyd, and Pablo Muñoz. 2016. Sharing Cities and Sustainable Consumption and Production: Towards an Integrated Framework. Journal of Cleaner Production 134: 87-97. [CrossRef] 
Daveiro, Raphael, and Robert Vaughan. 2016. Assessing the Size and Presence of the Collaborative Economy in Europe. Brussels: European Commission. [CrossRef]

De Groen, Willem Pieter, and Ilaria Maselli. 2016. The Impact of the Collaborative Economy on the Labour Market. CEPS Special Report, 138. [CrossRef]

De Stefano, Valerio. 2016. La gig economy y los cambios en el empleo y la protección social. Gaceta Sindical 27: 149-72.

Denning, Stephen. 2014. An Economy of Access is Opening for Business: Five Strategies for Success. Strategy $\mathcal{E}$ Leadership 42: 14-21. [CrossRef]

Dillahunt, Tawanna R., and Amelia R. Malone. 2015. The Promise of the Sharing Economy Among Disadvantaged Communities. Paper presented at 33rd Annual ACM Conference on Human Factors in Computing Systems-CHI '15, Seoul, Korea, April 18-23. [CrossRef]

Dills, Angela K., and Sean Mulholland. 2015. Ride-sharing, Fatal Crashes and Crime. SSRN Electronic Journal 6: 408-18.

Emekter, Riza, Yambin Tu, Benjamas Jirasakuldech, and Min Lu. 2015. Evaluating Credit Risk and Loan Performance in Online Peer-to-Peer (P2P) Lending. Applied Economics 47: 54-70. [CrossRef]

Ert, Eyal, Aliza Fleischer, and Nathan Magen. 2016. Trust and Reputation in the Sharing Economy: The Role of Personal Photos in Airbnb. Tourism Management 55: 62-73. [CrossRef]

Ertz, Myriam, Fabien Durif, and Manon Arcand. 2016. Collaborative Consumption: Conceptual Snapshot at a Buzzword. Journal of Entrepreneurship Education 19: 1-23. [CrossRef]

Ertz, Myriam, Fabien Durif, and Manon Arcand. 2018. A Conceptual Perspective on Collaborative Consumption. AMS Review. [CrossRef]

Ertz, Myriam, and Emine Sarigöllü. 2019. Assessing the Potential of Sustainable Value Chains in the Collaborative Economy. Sustainability 11: 390. [CrossRef]

Etzioni, Amitai. 2017. Cyber Trust. Journal of Business Ethics, 1-13. [CrossRef]

European Commission. 2018. Study on the Assessment of the Regulatory Aspects Affecting the Collaborative Economy in the Tourism Accommodation Sector in the 28 Member States. Brussels: European Commission. [CrossRef]

Feeney, Matthew. 2015. Is Ridesharing Safe? Cato Institute Policy Analysis 767: 1-15.

Freedland, Mark R., and Jeremias Prassl. 2017. Employees, Workers, and the 'Sharing Economy': Changing Practices and Changing Concepts in the United Kingdom. Oxford Legal Studies Research Paper. [CrossRef]

Freedman, Seth, and Ginger Zhe Jin. 2017. The Information Value of Online Social Networks: Lessons from peer-to-peer lending. International Journal of Industrial Organization 51: 185-222. [CrossRef]

Fremstad, Anders. 2017. Is There a Future for Sharing? A Comparison of Traditional and New Institutions. Journal of Institutional Economics 14: 1-22. [CrossRef]

Frenken, Koen, and Juliet Schor. 2017. Putting the Sharing Economy into Perspective. Environmental Innovation and Societal Transition 23: 3-10. [CrossRef]

Gadellaa, Stefanie. 2017. Incumbent Businesses within the Access Economy. Master's Thesis, University of Utrecht, Utrecht, The Netherlands.

Garikapati, Venu M., Ram M. Pendyala, Eric A. Morris, Patricia L. Mokhtarian, and Noreen McDonald. 2016. Activity Patterns, Time Use, and Travel of Millennials: A Generation in Transition? Transport Reviews 36: 558-84. [CrossRef]

Ge, Ruyi, Juan Feng, Bin Gu, and Pengzhu Zhang. 2017. Predicting and Deterring Default with Social Media Information in Peer-To-Peer Lending. Journal of Management Information Systems 34: 401-24. [CrossRef]

Ginés-i-Fabrellas, Anna, and Sergi Gálvez-Durán. 2016. Sharing economy vs. uber economy y las fronteras del Derecho del Trabajo: La (des)protección de los trabajadores en el nuevo entorno digital. InDret: Revista Para el Análisis del Derecho 1: 1-44.

Greenwood, Brad N., and Sunil Wattal. 2017. Show Me the Way to go Home: An Empirical Investigation of Ride_Sharing and Alcohool Related Motor Vehicle Fatalities. MIS Quarterly Management Information Systems 41: 163-87. [CrossRef]

Hamari, Juno, Mimmi Sjöklint, and Antti Ukkonen. 2015. The Sharing Economy: Why People Participate in Collaborative Consumption. Journals of the Association for Information Science and Technology 67: 2047-59. [CrossRef] 
Hwang, Jiyoung, and Merlyn A. Griffiths. 2017. Share More, Drive Less: Millennials Value Perception and Behavioral Intent in Using Collaborative Consumption Services. Journal of Consumer Marketing 34: 132-46. [CrossRef]

Hyde, Lewis. 1983. Imagination and the Erotic Life of Property. New York: Random House.

Jarne-Muñoz, Pablo. 2016. El consumo colaborativo en España: Experiencias relevantes y retos de ruturo. Revista CESCO de Derecho de Consumo 17: 62-75.

John, Nicholas A. 2013. The Social Logics of Sharing. Communication Review 16: 113-31. [CrossRef]

JPMorgan. 2015. The Online Platform Economy: What Is the Growth Trajectory? JPMorgan Chase Institute. Available online: https://www.jpmorganchase.com/corporate/institute/document/jpmc-institute-online-platform-econbrief.pdf (accessed on 29 March 2018).

Jourová, Véra. 2017. Key Findings about Problems Consumers Face in the Collaborative Economy. Brussels: European Commission Fact Sheet, pp. 1-3.

Lan, Jing, Yuge Ma, Dajian Zhu, Diana Mangalagiu, and Thomas F. Thornton. 2017. Enabling value co-creation in the sharing economy: The case of mobike. Sustainability 9: 1504. [CrossRef]

Malin, Brenton J., and Curry Chandler. 2017. Free to Work Anxiously: Splintering Precarity among Drivers for Uber and Lyft. Communication, Culture and Critique 10: 382-400. [CrossRef]

McDonald, Noreen C. 2015. Are Millennials Really the 'Go-Nowhere' Generation? Journal of the American Planning Association 81: 90-103. [CrossRef]

Melián-González, Santiago. 2017. What Do Consumers Appreciate about On-Demand Economy Workers? Available online: http://dx.doi.org/10.2139/ssrn.3011213 (accessed on 29 March 2018).

Melián Gonzalez, Santiago, and Jacques Bulchand Gideumal. 2015. Competencias requeridas por el nuevo trabajo en turismo. Investigaciones Turísticas 10: 76-89. [CrossRef]

Mollick, Ethan. 2014. The Dynamics of Crowdfunding: An Exploratory Study. Journal of Business Venturing 29: 1-16. [CrossRef]

Möhlmann, Mareike. 2015. Collaborative Consumption: Determinants of Satisfaction and the Likelihood of Using a Sharing Economy Option Again. Journal of Consumer Behaviour 14: 193-207. [CrossRef]

Mtsweni, Jabu, and Legand Burge. 2014. The Potential Benefits of Mobile Microwork Services in Developing Nations: Research Opportunities and Challenges. Paper presented at 2014 IST-Africa Conference, Le Meridien Ile Maurice, Mauritius, May 7-9. [CrossRef]

Murillo, David, Heloise Buckland, and Esther Val. 2017. When the Sharing Economy becomes Neoliberalism on Steroids: Unravelling the Controversies. Technological Forecasting and Social Change 125: 66-76. [CrossRef]

Nadler, Samuel. 2014. The Sharing Economy: What Is It and Where Is It Going? Master's Thesis, Sloan School of Managements, Massachusetts Institute of Technology, Cambridge, MA, USA. Available online: http://dspace.mit.edu/handle/1721.1/90223 (accessed on 20 January 2018).

Park, Jiyong, Junetae Kim, and Byungtae Lee. 2016. Are Uber Really to Blame for Sexual Assault?: Evidence from New York City. Paper presented at 18th Annual International Conference on Electronic Commerce e-Commerce in Smart Connected World-ICEC '16, Suwon, Korea, August 17-19. [CrossRef]

Pesole, Annarosa, Cesira Urzi Brancati, Enrique Fernández-Macías, Federico Biagi, and Ignacio González Vázquez. 2018. Platform Workers in Europe Evidence from the COLLEEM Survey. Luxembourg: Publications Office of the European Union. [CrossRef]

Petriglieri, Gianpiero, Susan J. Ashford, and Amy Wrzesniewski. 2019. Agony and Ecstasy in the Gig Economy: Cultivating Holding Environments for Precarious and Personalized Work Identities. Administrative Science Quarterly 64: 124-70. [CrossRef]

Ranzini, Giulia, Gemma Newlands, Guido Anselmi, Alberta Andreotti, Thomas Eichhorn, Michael Etter, Christian Hoffman, Sebastian Jürss, and Christoph Lutz. 2017. Millennials and the Sharing Economy: European Perspectives. SSRN Electronic Journal, 1-71. [CrossRef]

Ravenelle, Alexandrea J. 2017. Sharing Economy Workers: Selling, not Sharing. Cambridge Journal of Regions, Economy and Society 10: 281-95. [CrossRef]

Sagardoy-de-Simón, Iñigo, and Pilar Núñez-Cortés-Contreras. 2017. Economía colaborativa y relación laboral: ¿un binomio conflictivo? Cuadernos de Pensamiento Político 53: 93-102.

Schor, Juliet B. 2014. Debating the Sharing Economy. A Great Transition Initiative Essay, 1-19. [CrossRef] 
Schor, Juliet B. 2017. Does the Sharing Economy Increase Inequality within the Eighty Percent?: Findings from a Qualitative Study of Platform Providers. Cambridge Journal of Regions, Economy and Society 10: 263-79. [CrossRef]

Schor, Juliet B., and William Attwood-Charles. 2017. The 'Sharing' Economy: Labor, Inequality, and Social Connection on For-Profit Platforms. Sociology Compass 11: 1-16. [CrossRef]

Schwartz, David L., and Lesli Oster. 2018. Bridges II: The Law—STEM Alliance \& Next Generation Innovation. Northwestern University Law Review Online 112: 133-76.

Smorto, Guido. 2016. The Sharing Economy as a Means to Urban Commoning. Comparative Law Review 7: 1-22.

Srnicek, Nick. 2017. The Challenges of Platform Capitalism: Understanding the Logic of a New Business Model. Juncture 23: 254-57. [CrossRef]

Sundararajan, Arun. 2014. Peer-to-peer Businesses and the Sharing (Collaborative) Economy: Overview, Economic Effects and Regulatory Issues. In The Power of Connection: Peer-to-Peer Businesses; Hearings, 15 January 2014. Available online: https://docs.house.gov/meetings/SM/SM00/20140115/101613/HHRG-113-SM00-20140115SD003-U1.pdf (accessed on 31 March 2018).

Sung, Eunsuk, Hongbum Kim, and Daeho Lee. 2018. Why do people consume and provide sharing economy accommodation? A sustainability perspective. Sustainability 10: 2072. [CrossRef]

Ter Huurne, Maarten, Amber Ronteltap, Rense Corten, and Vicent Buskens. 2017. Antecedents of Trust in the Sharing Economy: A Systematic Review. Journal of Consumer Behaviour 16: 485-98. [CrossRef]

Tescasiu, Bianca, Gheorghe Epuran, Alina Simona Tecau, and Iona Bianca Chitu. 2018. Innovative forms of economy and sustainable urban development-Sharing tourism. Sustainability 10: 3919. [CrossRef]

Teubner, Tim, and Christoph M. Flath. 2015. The Economics of Multi-hop Ride Sharing: Creating New Mobility Networks through IS. Business and Information Systems Engineering 57: 311-24. [CrossRef]

Todolí-Signes, Adrián. 2017. The 'Gig Economy': Employee, Self-Employed or the Need for A Special Employment Regulation? Transfer 23: 193-205. [CrossRef]

Weber, Thomas A. 2016. Product Pricing in a Peer-to-Peer Economy. Journal of Management Information Systems 33. [CrossRef]

Xu, Yilan, Carrie Johnson, Suzanne Bartholomae, Barbara O’Neill, and Michael Gutter. 2015. Homeownership among Millennials: The Deferred American Dream? Family and Consumer Sciences Research Journal 44: 201-12. [CrossRef]

Zwick, Austin. 2017. Welcome to the Gig Economy: Neoliberal Industrial Relations and the Case of Uber. GeoJournal 2016: 1-13. [CrossRef] 